\title{
Social entrepreneurship
}

\author{
Dr. Tasavori, Misagh \\ Dr. Zaefarian, Reza
}

Book Review- Value-centered entrepreneurs and their companies

Social entrepreneurship as a field of academic enquiry has attracted the attention of growing number of scholars. Social entrepreneurs employ innovative strategies to address social problems. There is no consensus among scholars whether social entrepreneurship is limited to non-profit organizations or whether it can be pursued by for-profit companies. While some researchers are arguing on the definition and boundaries of social entrepreneurship, the authors of the book, "Value-centered entrepreneurs and their companies" offer the term of "value-centred entrepreneurs" to refer to the for-profit companies that their primary mission is social. These entrepreneurs pursue the mission of being socially responsible, protecting the environment and considering the needs of all stakeholders. As a result, they do not want to earn profit as their sole mission but try to create a balance between social and economic mission. They employ entrepreneurship as a means to achieve their goal of changing society and creating a better life for everyone.

The authors of the book, Dr. David Choi and Prof. Edmund Gary from Loyola Marymount University attempt to explore what is unique, interesting and special about these highly unorthodox leaders and how they build their profitable and socially responsible business enterprises. In this regard, they focus on answering some of the questions that other entrepreneurs may have when pursuing this path:

1. Is it really possible to be good and do well?

2. What are the real motivations and objectives of value-centered entrepreneurs?

3. Do they give priority to earning profit or pursuing a social mission?

4. Do they aim to be competitive and grow?

5. Who will financially support these entrepreneurs?

6. How do they balance earning money and serving a social mission?

7. Do they treat their employees, the environment and their communities differently?

8. How do they manage building a responsible company in the competitive environment?

9. Do they sell their companies to make profit?

10. Do they donate money more than other companies?

To answer these questions, the authors first develop some criteria which lead to the identification of 46 value-centred entrepreneurial firms. Built upon first and secondary data, they recognize ten commonalities in management practices of these firms. Each of these commonalities and as a result guideline for future value-centred entrepreneurs is discussed in each chapter of the book. These include:

1. Commit to a (meaningful) purpose. View the business as a vehicle for achieving both financial gain and social/environmental mission.

2. Raise capital with mission in mind. Find investors who also value social mission.

3. Hire talented employees with shared values. Give priority to recruitment of employees who share similar personal values with you and then evaluate their professional competencies. 
4. Promote your company's value. Create advantage for your company by promoting your organization values and differentiating yourself from competitors.

5. Build a cohesive, dedicated team. Built upon the shared values of employees and your organization, create an environment that fosters loyal and committed employees.

6. Make money, but also make exceptions. The authors agree with earning profit and even encourage entrepreneurs to cut their costs and increase their profitability. However, they advise entrepreneurs to be open to consider exceptions whenever their social goals necessitate.

7. Minimize your environmental and social footprints. Being proactive in developing solutions that reduce firm's negative social and environmental impacts.

8. Stay with it for the long haul. Stick to your goals and do not sacrifice your social goals for short-term profit. When you decide to sell your business, find a buyer that maintains your social goals.

9. Make giving a priority. Donating money and time should be in the main agenda of the firm and principal reason of the firm being.

This book is a very interesting, stimulating and easy to read. Although it does not deal directly with management and entrepreneurship, it offers a considerable contribution to the development of social entrepreneurship as a field of study. The findings of this book corroborate that socially entrepreneurial practices can also be employed by for-profit firms. The interviews of the authors with 46 companies in this area have provided in-depth insights to the activities of value-centered entrepreneurs and how they build their organization. This book not only enable the researchers to have a better understanding of the activities of these groups of social entrepreneurs but also gives a detailed road map to those entrepreneurs whose mission go beyond profitability. Therefore, this book is recommended to both academics and practitioners.

Dr. Misagh Tasavori, Lecturer, Essex Business School, University of Essex

Dr. Reza Zaefarian, Assistant Professor at the Faculty of Entrepreneurship, University of Tehran 